\title{
Author Correction: Charge-generating mid-gap trap states define the thermodynamic limit of organic photovoltaic devices
}

\author{
Nasim Zarrabi, Oskar J. Sandberg (1), Stefan Zeiske, Wei Li, Drew B. Riley, Paul Meredith (1) \& Ardalan Armin (1)
}

Correction to: Nature Communications https://doi.org/10.1038/s41467-020-19434-0, published online 04 November 2020.

The original version of the Supplementary Information associated with this Article contained an error in Supplementary Fig. 8 in which the units on the $y$-axes were incorrectly labelled as '\%', instead of 'a.u.'. The HTML has been updated to include a corrected version of the Supplementary Information.

Published online: 04 January 2021

\section{Additional information}

Supplementary information is available for this paper at https://doi.org/10.1038/s41467-020-20626-x.

(c) (i) Open Access This article is licensed under a Creative Commons Attribution 4.0 International License, which permits use, sharing, adaptation, distribution and reproduction in any medium or format, as long as you give appropriate credit to the original author(s) and the source, provide a link to the Creative Commons license, and indicate if changes were made. The images or other third party material in this article are included in the article's Creative Commons license, unless indicated otherwise in a credit line to the material. If material is not included in the article's Creative Commons license and your intended use is not permitted by statutory regulation or exceeds the permitted use, you will need to obtain permission directly from the copyright holder. To view a copy of this license, visit http://creativecommons.org/licenses/by/4.0/.

(c) The Author(s) 2021 